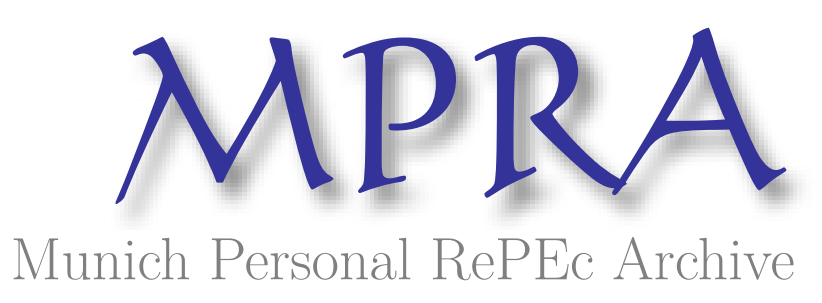

\title{
Wealth and the Capitalist Spirit
}

Francis, Johanna L.

Fordham University

15 August 2007

Online at https://mpra.ub.uni-muenchen.de/5985/

MPRA Paper No. 5985, posted 28 Nov 2007 00:10 UTC 


\title{
Wealth and the Capitalist Spirit
}

\author{
Johanna L. Francis* \\ Department of Economics \\ Fordham University
}

August 2007

\begin{abstract}
The wealth distribution in the U.S. is more unequal, or skewed to the right, than either the income or earnings distribution, a fact current models of saving behavior have difficulty explaining. Using Max Weber's (1905) idea that individuals may have a 'capitalist spirit', I construct and simulate a model where some individuals accumulate wealth for its own sake rather than as deferred consumption. Including capitalist-spirit preferences in the standard life cycle model, with no other modifications, generates a skewness of wealth consistent with that observed in the U.S. economy. Furthermore, capitalist-spirit preferences provide a way to generate decreasing risk aversion with increases in wealth without resorting to idiosyncratic rates of time preference.
\end{abstract}

JEL Classification Numbers: D31, E21, J23

Keywords: capitalist spirit, life cycle, wealth

* Department of Economics, E-507 Dealy Hall, 441 East Fordham Road, Bronx, NY, 10458, USA. email: ajofrancis@fordham.edu. Acknowledgements: I wish to thank Christopher D. Carroll, Laurence Ball, Thomas Lubik, Bart Moore, Berna Demiralp, Fabian Valencia and seminar participants at Johns Hopkins University, Fordham University and the Congressional Budget Office for valuable comments. 


\section{Introduction}

Wealth is highly concentrated and more unequally distributed than income or earnings (Kennickell, 2003). In the United States, the wealthiest 1 percent of households own one third of the wealth of the entire economy, but receive only 15 percent of earnings and less than 10 percent of income, while a significant fraction of the population, almost 10 percent, holds little or no wealth at all (Diaz, Quadrini, and Rios-Rull, 1997). Explaining wealth inequality is a challenge for most models of saving behavior. Specifically, quantitative life cycle models imply a far tighter relationship between earnings and wealth than that observed in U.S. data (Hendricks, 2004). Of course, much of the inequality in wealth is generated by permanent income inequality. Yet wealth is even more concentrated than income, so differences in saving behavior must also drive the skewness in the wealth distribution. Dynan, Skinner, and Zeldes (2004)find that individuals with higher income have higher saving rates. This fact is cannot be explained by models of saving behavior that assume the wealthy are scaled up versions of the poor. Further, data on portfolio composition indicates that the wealthy hold much riskier portfolios than the rest of the population (Carroll, 2002), implying that they have a higher tolerance for risk than the rest of the population.

In this paper, I propose a quantitative life cycle model that takes its inspiration from the qualitative literature on the capitalist spirit, in which individuals with high permanent income have a stronger incentive for wealth accumulation than individuals with low permanent income. I focus on the evolution of the distribution of wealth for a typical cohort of individuals as the cohort ages. I specifically analyze how measures of wealth dispersion and skewness change as the cohort ages. The life cycle model with capitalist-spirit preferences generates a distribution of wealth consistent with U.S. data. It is able to replicate the concentration of wealth among the income rich, wealth concentration within age groups, and continued asset accumulation after retirement. Individuals with capitalist-spirit preferences also exhibit declining risk aversion with increases in wealth.

Heterogeneous human capital development and the transfer of earning ability across generations contribute to permanent income inequality and thus to wealth inequality (Huggett, Ventura, and Yaron, 2003). However, even models that incorporate education, demographic factors and idiosyncratic permanent and temporary income shocks are unable to generate wealth inequality beyond that which comes from differences in permanent income (Huggett, 1996). In order to capture the extreme right skewness in the wealth distribution, we need a mechanism to promote saving behavior that differs between high and low permanent income earners (Carroll, 2000). Recent work on understanding the skewness of the wealth distribution has focused on dynastic models in which individuals are part of long lived families and bequests form the predominant intergenerational link (De Nardi, 2004; Fuster, 2000). These models became popular following the controversial evidence that the pure 
life-cycle component of the aggregate U.S. capital stock has been historically relatively small (approximately 20 percent) and therefore most capital accumulation occurs through intergenerational transfers (Kotlikoff and Summers, 1981). Bequest motives were also proposed as an explanation for the 'saving puzzle': contrary to the prediction of the precautionary saving model, retired individuals, especially wealthier retirees, typically do not de-cumulate their wealth appreciably after retirement and some even save (Dynan, Skinner, and Zeldes, 2004). There is evidence that bequest motives do play an important role in wealth accumulation and may explain the extreme accumulation of wealth among a small group of families. However, intergenerational transfers of wealth cannot explain why there is no significant difference in the rate of asset de-cumulation between the elderly with children and those without (Hurd, 1986). Moreover, it is difficult to determine whether bequests are intentional or accidental (Hendricks, 2002) and accidental bequests should have a limited impact on wealth concentration.

Weber (1905) and Smith (1776) before him proposed that individuals have a 'capitalist spirit': an innate desire to be frugal, accumulating wealth throughout their lifetime. ${ }^{1}$ The idea that individuals have a direct preference for wealth is most easily interpreted through modification of the utility function, so that utility expresses preferences not only over consumption (and possibly leisure) but also over wealth holdings directly.

In addition to the three standard motivations for saving analyzed in the extant literaturefor retirement, for precautionary purposes, and for bequests-I argue that a direct preference for wealth enables the standard model to explain the data on wealth accumulation better. In the next section, I review some important facts about the U.S. wealth and income distributions; section three discusses the capitalist spirit. Section four sets out the model with capitalist-spirit preferences, section five discusses the simulation technique and section six presents the simulation results. Section seven lays out the claims regarding risk aversion and section eight concludes with some ideas for future work.

\section{Stylized Facts}

The main source of microeconomic data on wealth for the U.S. is the Survey of Consumer Finances (SCF) which collects detailed information every three years about wealth and portfolio composition for a cross-section of households. ${ }^{2}$ Table 1 displays the wealth dis-

\footnotetext{
${ }^{1}$ Weber proposed the existence of a 'spirit of capitalism'. He writes "The peculiarity of this philosophy of avarice appears to be the ideal of the honest man of recognized credit, and above all the idea of a duty of the individual toward the increase of his capital, which is assumed as an end in itself." pg. 51 (Weber, 1905) (Italics are mine.) Or "It is thought of so purely as an end in itself, that from the point of view of the happiness of, or utility to, the single individual, it appears entirely transcendental and absolutely irrational." pg. 53 (Weber, 1905) In the literature, 'direct preference for capital' is synonymous with the 'the capitalist spirit' suggested by Weber.

${ }^{2}$ The SCF was explicitly designed to measure the balance sheet of households and the distribution of wealth. It over-samples wealthy households by including a representative population sample and a list
} 
tribution across 5 waves of the SCF, where the amount of wealth held by individuals in the top percentiles of the wealth distribution is shown (Kennickell, 2003). The most striking aspect of the table is how little wealth the first 5 deciles of the wealth distribution hold and, conversely, how much the top five percent holds. The top five percent of the wealth distribution holds more than 50 percent of aggregate wealth. The bottom 50 percent of the wealth distribution holds less than 5 percent of aggregate wealth. The Gini coefficient for the wealth distribution averaging 0.79 over the last decade confirms this skewness.

Although few countries exhibit the extreme concentration of wealth observed in the U.S., even moderately egalitarian countries such as Sweden have more concentrated distributions of wealth than income (De Nardi, 2004) and other countries such as the UK are catching up to the level of inequality in the U.S. (Banks, Blundell, and Smith, 2000). In comparison to these wealth statistics, table 2 (from Quadrini 1999) depicts the normal income distribution for two waves of the SCF, 1989 and $1992^{3}$ It is readily observable that income, while fairly unequal, is distributed much more equally than wealth. The top 5 percent of the income distribution earns approximately one third of aggregate income. The Gini coefficient for income, which averages 0.56 , is also much lower than for the wealth distribution.

The data in these tables demonstrates wealth in the U.S. is much more concentrated than income and that this phenomena has been persistent over at least the past decade. The fact that income is less concentrated than wealth implies that income heterogeneity alone cannot explain the concentration of wealth. It appears that high-income individuals have higher saving rates. Hence, we turn to saving behavior for an explanation of wealth concentration. Table 3 presents the responses individuals gave as the most important reasons for their family's saving, distributed by type of reason, in the SCF (see Kennickell 2003). The predominant reason individuals report for saving out of income was for liquidity. This response is often interpreted as buffer stock saving (Carroll, 1992), where individuals save to buffer the impact of transitory income shocks on their consumption behavior. The second most important reason given for saving was for retirement. Very few individuals (at most 5 percent) indicated that saving for their family, for example for bequest purposes, was important. Although surveys should be treated cautiously, the responses suggest that, among the general population, saving for bequests is less important than saving for retirement and life cycle purposes, such as education, health care and liquidity.

\section{What is the Capitalist Spirit?}

The literature on saving behavior attempts to explain four basic facts: first, wealth holdings are much more concentrated in the upper tail of the wealth distribution than income

sample drawn from tax records. Therefore, it is the most accurate representation available of the upper portion of the U.S. wealth distribution.

${ }^{3}$ Normal income is an empirical measure that approximates permanent income. (Kennickell, 2003) 
(Castañeda, Díaz-Giménez, and Rios-Rull, 2003), second, wealth is unequally distributed within an age group in the U.S. in addition to being unequally distributed across the population (Huggett, 1996), third, there is little empirical evidence that elderly people de-cumulate their wealth in the manner predicted by precautionary saving models (Hurd, 1986), and fourth, wealthy individuals tend to hold much riskier portfolios than the rest of the population (Carroll, 2002). Recently researchers have suggested that these facts can be explained by a direct preference for wealth (Zou, 1995; Bakshi and Chen, 1996; Carroll, 2000).

The idea that some individuals value wealth for its own sake traces back to Max Weber (1905). For individuals with capitalist-spirit preferences, acquisition is not only a means for the satisfaction of material needs but also an end in itself. Capitalist spirit preferences are conceptually similar to 'wealth-as-status', where individuals accumulate wealth to gain prestige, social status and power in society; see Frank (1985) especially, as well as Cole, Malaith, and Postlewaite (1992) and Bakshi and Chen (1996).

Zou $(1994,1995)$ was the first in the modern literature to examine a direct preference for wealth; following a paper by Kurz (1968), he demonstrates that in a non-stochastic growth model, a direct preference for wealth (held as capital) reduces the rate of time preference, generating an increase in capital accumulation, and thus potentially explaining the link between saving and growth. Bakshi and Chen (1996) examine the implications of a desire for status, measured in terms of wealth holding either relative to a community wealth level or in absolute terms, for asset pricing. They determine that when investors also care about relative or absolute social status, the propensity to consume and risk aversion will depend on social standards and thus contribute to stock price volatility, among other things. Smith (1999) develops a formal stochastic growth model incorporating capitalist spirit preferences. He demonstrates that a direct preference for capital lowers the effective rate of time preference, resulting in a faster accumulation of capital and an acceleration in growth, confirming Zou's result in a stochastic environment. Reiter (2004) develops a general equilibrium model in which individuals have capitalist-spirit preferences and the option of choosing an entrepreneurial venture. He finds that capitalist spirit preferences when combined with entrepreneurial ventures can explain at least some of the skewness of wealth.

\section{Model with Capitalist Spirit Preferences}

I develop a life cycle model that captures the main determinants of savings behavior: to finance post-retirement consumption, to keep a buffer stock of wealth for precautionary reasons, and to possibly leave a bequest. In addition, I include the possibility that individuals who reach a particular threshold of wealth continue to accumulate wealth purely for the sake of it. By permitting households to value wealth differently from consumption, I am 
able to model the idea that the marginal utility gained from an extra unit of accumulated wealth declines more slowly than the marginal utility gained from an additional unit of consumption. This assumption provides a reason for individuals to continue to accumulate wealth that does not exist in otherwise fully specified life cycle models. Capitalist-spirit preferences differ from bequest motives in that they provide a rationale for all wealthy households to accumulate additional wealth, not only those with an intention to leave a bequest. But they have a flexible interpretation, although they are explicitly formulated to capture a direct preference for wealth throughout the life cycle, they can alternatively be interpreted as a bequest motive and do effectively function as one. The difference between this form of bequest motive and the standard bequest motive in the literature, e.g., Cagetti and De Nardi (2006), is that households value bequests (written as wealth here) and consumption differently. It has been argued by Carroll (2000), for example, that the marginal utility from bequests should diminish at a slower rate than the marginal utility from consumption. This luxury good property of bequests is consistent with the data that show wealthier individuals are more likely to save additional increments of permanent income.

\subsection{Preferences}

Households derive utility from consumption and wealth holdings. I modify the canonical utility function, so that is non-homothetic across consumption and wealth, but maintains time separability. In contrast to the capitalist-spirit literature, in which preferences for consumption and wealth take on a multiplicative form, I consider additive preferences. Additive preferences appear better able to capture the behavior of wealthy households, as they require no restrictions on whether wealth and consumption are compliments or substitutes. ${ }^{4}$ Each part of the utility function has a constant relative risk aversion form and the intraperiod utility function describing the household's preference over wealth includes a positive modified Stone-Geary parameter (Carroll, 2000) ${ }^{5}$. This parameter ensures households consume a subsistence level, or that not all households have an operative preference for wealth. Only households who reach a threshold level of income will have an operative capitalist spirit. In this manner, the model is able to capture both the behavior of the wealthy and that of the remainder of the population. The utility function is given by

$$
U\left(C_{t}, W_{t}\right)=u\left(C_{t}\right)+v\left(W_{t}\right)=\left[{\frac{C_{t}^{1-\rho}}{1-\rho}}^{1-\rho} \frac{\left(W_{t}+\gamma\right)^{1-\alpha}}{1-\alpha}\right]
$$

\footnotetext{
${ }^{4}$ Luo and Young (2003) use a multiplicative version of capitalist-spirit preferences in an otherwise standard model of precautionary. They find that the multiplicative version of capitalist-spirit preferences reduces the skewness of the wealth distribution.

${ }^{5}$ This parameter, $\gamma$, is similar in spirit to a Stone-Geary parameter (which is negative in its original formulation) in the sense that it provides a threshold level for wealth. The actual Stone Geary parameter is a subsistence level of consumption for a particular good (Stone, 1954; Geary, 1949-50).
} 
where $\alpha, \rho$ and $\gamma$ are positive constants with $\alpha<\rho$. The intraperiod functions, $u\left(C_{t}\right)$ and $v\left(W_{t}\right)$, are strictly concave and continuously differentiable. As usual, $\rho$ is the coefficient of relative risk aversion for consumption while $\alpha$ controls the demand for wealth. The assumption that $\alpha<\rho$ implies as the marginal utility of wealth approaches zero, the share of income going to wealth approaches one. See the appendix for proof of this claim. Poor individuals will not over accumulate wealth since the assumption that $\gamma>0$ implies there is a threshold level of consumption, below which wealth accumulation will be small. In other words, when the marginal utility of wealth is high, individuals will save little. The constant relative risk aversion preference structure exhibits prudence (the marginal utility curve is convex) inducing precautionary behavior in the presence of uncertainty. The parameter $\gamma$ also generates heterogeneity in the demand for wealth. Under these parameter restrictions, the majority of individuals will behave as precautionary savers while a percentage of the population will have a capitalist spirit motive for saving as well.

\subsection{Income Process}

As in most models of precautionary saving, the household knows its current permanent income with certainty but is uncertain about its future income. Labor income is decomposed into two multiplicative components: a permanent component and a temporary income shock, $\varepsilon_{t+1}$, as follows:

$$
\begin{aligned}
Y_{i, t+1} & =P_{i, t+1} \varepsilon_{i, t+1} \\
P_{i, t+1} & =G_{t} P_{i, t} \Psi_{i, t+1}
\end{aligned}
$$

where $Y_{i, t+1}$ is individual income, $P_{i, t+1}$ is the permanent component of income. Following Friedman (1957), $P_{i, t+1}$, is the level of income that would obtain without transitory shocks, rather than the present discounted value of future income streams. Here $\varepsilon_{i, t+1}$ represents a transitory income shock that is independently and identically distributed, taking on the value of 0 with probability $p$, where $p$ is very small, and the value of 1 with probability $1-p .{ }^{6}$ I assume permanent income grows at the same deterministic potentially time varying rate, $G_{t}$, for all individuals. $\Psi_{i, t}$ is an innovation to the permanent component of income and follows an i.i.d. lognormal distribution with mean 1 and standard deviation of $\sigma_{\Psi}$. The log of the permanent component of income, $\ln P_{t}$, evolves as a random walk with drift. This specification has been widely used in empirical work and therefore appears to fit the data reasonably well (Carroll and Samwick, 1997). ${ }^{7}$ Under the assumption that there is a

\footnotetext{
${ }^{6}$ Since my focus is on the wealth distribution, I ignore other types of transitory shocks, for example negative health shocks (Huggett and Ventura, 2000).

${ }^{7}$ The fact that the shocks are i.i.d means that the consumer cares only about the total amount of assets she has to consume, not about their origin, i.e., as wealth or income. In the typical problem of this type, we could then normalize by the level of total assets (called cash-on-hand by Deaton 1991). However, since the utility function is non-homothetic such a normalization is unavailable.
} 
positive probability income will be zero in any given period, the consumer will choose never to borrow against future income. Hence this assumption behaves like a liquidity constraint (Deaton, 1991). Households retire at age 65, after which earnings become deterministic

$$
Y_{i, t}=G_{R} P_{i, 64}
$$

where $P_{i, 64}$ is the household's permanent income in the year prior to retirement and $G_{R}$ is the growth of income during retirement, which is lower than the growth rate during working life.

\subsection{Decision Problem}

At the beginning of period $t$ households maximize the expected value of future consumption and wealth according to the following (individual subscripts are dropped here)

$$
\begin{aligned}
V\left(W_{t}, P_{t}\right) & =\max _{C_{t}} E\left(\sum_{t=0}^{T} \beta^{t}\left[u\left(C_{t}, W_{t}\right)\right]\right) \\
& =\max _{C_{t}} u\left(C_{t}, W_{t}\right)+\beta E_{t}\left[V\left(W_{t+1}, P_{t+1}\right)\right]
\end{aligned}
$$

subject to

$$
\begin{array}{r}
W_{t+1}=R\left(W_{t}-C_{t}\right)+Y_{t+1} \\
Y_{t+1}=P_{t+1} \varepsilon_{t+1} \\
P_{t+1}=G_{t} P_{t} \Psi_{t+1}
\end{array}
$$

where $W_{0}=0$ and $W_{T} \geq 0$. Variables are in real terms. $V(\cdot, \cdot)$ is the value function, $\beta$ is the discount factor which takes a value between 0 and $1, E_{t}$ is the expectations operator conditioned on information available at the beginning of period $t$, in particular current income is known, $W_{t}$ is current cash on hand, $Y_{t}$ is current income (as defined above), and $C_{t}$ is current consumption. Note that $W_{t}$, as written here, has a broader definition than asset holdings as it also includes current income. Uncertainty comes from permanent, $\Psi_{t}$, and transitory, $\varepsilon_{t}$, income shocks. The budget constraint implies that consumers can borrow and save freely at the risk free rate $R_{t}=\left(1+r_{t}\right)=R$, assumed to be constant. The

additively separable components of the utility function, $u\left(C_{t}\right)$ and $v\left(W_{t}\right)$ are both concave and continuously differentiable over the state space.

The optimal behavior is given by the Euler equation

$$
U_{t}^{c}\left(C_{t}, W_{t}\right)=\beta E_{t} R\left[U_{t+1}^{c}\left(C_{t+1}, W_{t+1}\right)+U_{t+1}^{w}\left(C_{t+1}, W_{t+1}\right)\right]
$$


substituting for the marginal utility of consumption and wealth ${ }^{8}$ gives:

$$
C_{t}^{-\rho}=\beta E_{t} R\left[C_{t+1}^{-\rho}+\left(W_{t+1}+\gamma\right)^{-\alpha}\right]
$$

The Euler equation for optimal behavior in this case has an additional term compared to the usual precautionary saving model: $\left(W_{t+1}+\gamma\right)^{-\alpha}$. The future benefit of saving is therefore larger, reducing current consumption and increasing the marginal utility of current consumption. In other words, when the capitalist spirit motive is operative, consuming $\epsilon$ more in period $t$ results in a loss of $E_{t+1} R \epsilon_{t+1}$ of future consumption and the additional utility that comes from holding part of $E_{t+1} R \epsilon_{t+1}$ in wealth. This is the mechanism through which capitalist-spirit preferences increase the willingness to delay consumption, increasing wealth holding at any $t$.

Consider an individual who receives a very low permanent income draw, below the level necessary for capitalist spirit preferences to be operative. For her, the marginal utility of wealth will be high, but she will consume all of her income where $\bar{C}=\gamma^{\frac{\alpha}{\rho}}$, where $W=0$ for all $C \leq \bar{C}$. Since $\gamma>0$ consumption will always be larger than wealth at low income levels. Similarly, for individuals with a high permanent income draw, the assumption that $\alpha<\rho$ means that wealth will be larger than consumption. As the individual's income grows, so does consumption causing the marginal utility of an additional unit of consumption to decline. At a certain point (dependent on the values of $\gamma$ and $\alpha$ ), as the marginal utility of consumption falls, the additional benefit the consumer receives from saving a unit of consumption will outweigh the benefit of consuming that unit and so the consumer will prefer to save it and gain the direct benefit of holding wealth.

\section{Simulation and Calibration}

I solve the model numerically using value function iteration. Beginning at the last period, the Euler equation is solved backwards, for the optimal consumption profile and corresponding level of wealth in each period. Solution of the model yields a set of consumption rules governing choices in each period. Individuals with operative capitalist-spirit preferences will behave differently from those without. For example, capitalist-spirit savers will not consume all of their accumulated wealth in the final period of life. But, individuals with low permanent income draws or precautionary savers will still choose to consume their remaining wealth in the last period.

I model individuals who are born at age 25 to avoid issues associated with post-secondary education. At the beginning of each period, the household receives labor income $Y_{t}$, the permanent component of which is drawn from a log-normal distribution. The mean and standard deviation of the permanent income distribution are calibrated to match U.S. log

\footnotetext{
${ }^{8}$ The finite horizon ensures there is a unique solution.
} 
income levels in approximately the 25th year of life, as measured in the SCF (1998) for households with a head who is between 25 and 35 years of age in the survey year. Thus individuals differ in log labor endowments at birth (in terms of the model, age 25)

$$
y_{1} \sim L N\left(\mu, \sigma_{1}^{2}\right)
$$

In each year following the first (25th) year, individuals receive an idiosyncratic permanent innovation to labor income. Income uncertainty in the model derives from two parameters: $p$, the probability of large negative temporary income shock, and $\sigma_{\Psi}$, which controls the uncertainty of the permanent shocks. Permanent income grows according to an aggregate annual growth rate $G_{t}$, which is constant during working life. At retirement, age 65 (model age 40), individuals no longer receive permanent or transitory income shocks. After retirement, they instead receive 70 percent of their previous period's (age 64) permanent income with certainty until their 80 th year, at which point they die. ${ }^{9}$ There is no population growth.

Table 4 displays the distribution of permanent income in the model by percentile and the Gini coefficient. In the simulations, the permanent income shock is drawn from a log normal distribution with mean 1.0 and standard deviation 0.10 . The standard deviation of the permanent shock implies that a one standard deviation shock increases or decreases earnings by approximately 10 percent. The transitory shock takes the value of 1.0 with probability 0.995 and the value of 0 with probability 0.005. After solving for a single consumption profile for a given set of parameter values, optimal profiles for 10,000 individuals are generated. Individuals are heterogenous in their receipt of permanent and transitory income shocks so that their optimal consumption profiles differ. There are also no restrictions on borrowing; however, the fact that in each period there is a small probability of receiving an unemployment shock (zero income) with a one year duration leads households to optimally choose not to borrow in any period. ${ }^{10}$ Table 5 presents the values of the parameters used in the simulation. The preference parameters $(\alpha, \beta, \gamma, \rho)$ are set using a model period of one year. The value of the discount factor, $\beta$, is set to the usual value in the literature (Cagetti, 2003). I choose the coefficient of relative risk aversion on consumption, $\rho$ to be two, which is conservative and consistent with the traditional range estimated in the empirical literature. This choice for the coefficient of risk aversion allows the results of my

\footnotetext{
${ }^{9}$ The assumption of known death age is made to focus on how capitalist-spirit preferences change the behavior of the wealthy, abstracting from other reasons individuals might save more. It is obviously an important simplification. In general, uncertainty over the timing of death contributes to over-saving in the sense that if individuals face a positive probability of living a long time, the fact that they are prudent (an implication of a CRRA utility function) means they will hesitate to run down their wealth as fast as if they knew their date of death.

${ }^{10}$ Removing the transitory shock and permitting households to borrow freely, in keeping with their intertemporal budget constraint, causes approximately 10 percent of the population to hold zero wealth optimally and another 5 to 9 percent to hold debt for a significant fraction of their lifetimes.
} 
model to be directly comparable to a baseline precautionary savings model, for example, Huggett and Ventura (2000).

The parameters unique to the model with capitalist-spirit preferences are given in table 6. It is difficult to calibrate $\alpha$ and $\gamma$ as there are few intuitive guides for these values. The capitalist-spirit parameter, $\alpha$, is theoretically restricted to be less than $\rho$ but this leaves a wide range of values between 0 and 2 as candidates. (See the appendix for a discussion) I investigate several values for each parameter, although I experimented with many more. I present the most interesting values. The accumulation modifying (intercept) parameter, $\gamma$, is calibrated (in the case with no income uncertainty) to ensure that there is sufficient consumption in the model. For example, if $\gamma$ is set too low, people will unrealistically use most of their income for wealth accumulation than for consumption, even if they are relatively poor.

\section{General Features of Model Economy: Cross Sectional Dis- tribution of Wealth}

I simulate the model under the set of parameter values discussed above for 10,000 households. In the simulation, all households start with zero asset holdings. Table 7 compares the model results (KS for capitalist spirit) with the standard precautionary saving model (PS) and the statistics on the wealth distribution in the U.S. economy from the SCF in 1998. The discrepancy between the reported SCF results in table 7 and table 1 is due to the fact that table 7 shows only the wealth concentration among individuals aged 25 to 65 in the U.S. economy, rather than for the entire economy. ${ }^{11}$

In the experiments, the accumulation modifying parameter, $\gamma$, is set in U.S. dollars. Income ranges between approximately $\$ 10,000$ and $\$ 400,000$ in the first year of life, thus values of $\gamma$ are chosen so that there will be heterogenous saving motivations in the model population and specifically so that the income poor will not defer consumption in order to accumulate wealth. The exact percentage of the model population with operative capitalist spirit preferences will depend on $\gamma$, the income distribution and the receipt of shocks.

Individuals who receive a low initial level of permanent income, do not accumulate high levels of wealth, but save for retirement and precautionary purposes using up all of their wealth before death. The value for the accumulation modification parameter helps to determine the skewness in the wealth distribution: lower values for $\gamma$ generate a more equal distribution of wealth because more households have operative capitalist spirit preferences and therefore save more while higher values of $\gamma$ generate a less equal distribution. But, because of the preference structure, the relationship between the accumulation modifica-

\footnotetext{
${ }^{11}$ The rational for looking at this range of ages, is that the retirement and old age process, including medical and end of life uncertainties are not specifically modeled here.
} 
tion parameter and the degree of wealth skewness is non-monotonic, so that increasing $\gamma$ does not translate one-to-one into additional skewness. For example, if $\gamma$ is set very high such as at $\$ 10,000,000$, the model essentially collapses to the baseline precautionary saving model because no individuals will have operative capitalist-spirit preferences. This result is reported with two different values for $\alpha$ in table 7 . From table 7 , with $\alpha=1$, we see that increasing $\gamma$ increases wealth inequality. The top one percent of the wealth distribution holds close to 15 percent of the wealth when $\gamma$ is larger, whereas in the case with a smaller $\gamma$ they hold 11 percent.

Similarly, the value of $\alpha$ also contributes to wealth inequality. The larger is $\alpha$, the faster the marginal utility of an additional unit of wealth declines (for a given $\gamma$ ). If the marginal utility gained from an additional unit of wealth declines faster, the effect on the concentration of the wealth distribution is attenuated. From table 7 , when $\alpha=1.7$, we see that overall inequality as measured by the Gini coefficient is slightly lower but the top percentiles of the wealth distribution hold a larger percent of the wealth. There is a balance however in the choice of $\alpha$, for very low values of $\alpha$ (for example, for $\alpha=0.8$ ), the marginal utility of consumption intersects the marginal utility of wealth at a relatively low level of wealth so that households consume only a small amount and prefer to save the rest, yielding a more equal distribution of wealth, but one in which everyone consumes very little.

Comparing any of the capitalist spirit parameterizations with the baseline model in line 2 of table 7 , we can see that the model with capitalist-spirit preferences generates significantly more wealth inequality than the baseline model with labor earnings risk and a life cycle structure. The model with capitalist-spirit preferences also provides a better match to the inequality reported in Survey of Consumer Finances data on line 1.

The type of exercise displayed in table 7 is limited by the fact we do not observe how the wealth distribution is changing across age levels; intuitively, individuals start their working life with few or no assets and begin to accumulate as they age. This means that part of the inequality in the cross-sectional wealth distribution comes from combining individuals who are at different stages in their life cycle. In the next section, I look at how much inequality exists within age groups to remove the contribution from differing ages.

\subsection{Distribution of wealth by age}

Huggett and Ventura (2000) point out that not only is wealth skewed cross-sectionally in the data, but that wealth skewness persists within age groups. The inequality in the wealth distribution is not driven solely by the mixing of 22 year old college graduates with no assets and 55 year old soon to be retired workers who have had 30 years of working life to accumulate wealth. Since I have calibrated a life cycle model, we can observe how the distribution of wealth changes as households in the model age. According to standard life cycle theories of saving, young people begin saving initially for precautionary purposes. 
As they age, individuals start saving for retirement, with accumulated savings reaching a peak shortly before retirement. Then, the elderly are supposed to de-cumulate their wealth smoothly following retirement. Thus in the life cycle model, consumers display 'hump-shaped' wealth profiles as shown in the upper panel of figure 1, which represents the profile of the median household over their lifetime from age 25 to age 80 (note the figure displays the ratio of wealth to permanent income and model age 0 corresponds to 25 , while model age 55 corresponds to 80 ). This typical profile implies that the household reaches its maximum wealth as it heads toward retirement. Once retirement occurs, wealth is drawn down progressively so that the individual dies with no assets. Since the model assumes no lifetime uncertainty, the median household in the simulations, which does not have operative capitalist spirit-preferences, will behave in this fashion.

The wealthier households in the simulated economy, however, do not behave according to the standard concave profile. For these households, savings in old age can in fact be higher than at 40-45 years old (roughly the time frame when wealth accumulation peaks in the baseline precautionary saving model). In fact, households with capitalist-spirit preferences will continue to accumulate (or not de-cumulate) wealth even through retirement. The typical profile is displayed in the lower panel of figure 1, where the ratio of wealth to permanent income for households in the top 10 percent of the wealth distribution continues to increase throughout their lifetime. This theoretical result has strong support in empirical studies of saving behavior of the elderly, for example, Brittain (1978), Menchik and David (1983), and Danziger, van der Graag, Smolensky, and Taussig (1983). Danziger, van der Graag, Smolensky, and Taussig (1983), in particular, show that many of the elderly not only do not run down their wealth during retirement, but spend less on consumption goods and services than the young at all levels of income, and the oldest of the elderly save the most at a given level of income.

Figure 1 about here.

Table 8 provides another look at the same picture, demonstrating what happens to the concentration of wealth over the life cycle for different choices of the capitalist-spirit parameters. The first panel in table 8 shows the life cycle dispersion of wealth when $\alpha$ is 1 and $\gamma$ is $\$ 150,000$. When $\alpha$ is 1 , the capitalist-spirit motive is relatively strong, promoting a more unequal distribution of wealth. But for a value of $\gamma$ equal to $\$ 150,000$, more people will have capitalist-spirit preferences, which will dampen some of the inequality induced by strong capitalist-spirit preferences.

Looking at table 8 , we see that wealth becomes more concentrated as individuals age, beginning from a moderately equal initial distribution of permanent income. At the beginning of age 25, the household has no wealth, within ten years, there is substantial wealth concentration even within age groups. Both the model with capitalist spirit preferences and 
the baseline precautionary saving model are shown in the table. In the baseline precautionary saving model, wealth also becomes more slightly more concentrated over time, the top 1 percent of the wealth distribution holds approximately 1 percent of the wealth initially. By the time individuals reach retirement age, the top 1 percent holds approximately 3 percent of the wealth. Following their 80th year, the precautionary savers consume all their wealth. In the model with capitalist-spirit preferences, in contrast, within the first five years wealth is more concentrated than permanent income in the initial period (where the top 1 percent of the income distribution receives 6.2 percent of the permanent income) and it becomes increasingly concentrated over time. Moreover, unlike the precautionary savers, those with capitalist-spirit preferences die with positive wealth. The model with capitalist-spirit preferences shows significant saving heterogeneity even within age groups.

In Panel 2 of table 8, the dispersion of the wealth distribution is shown for $\alpha=1.0$ and $\gamma=\$ 750,000$. The precautionary saving model results do not change from panel 1 of table 8 , as the parameters used are the baseline ones $(\rho=2)$. For the model with capitalistspirit preferences, after 20 years, the top percentile of the wealth distribution holds a larger fraction of wealth, 10.1 percent, than they do of permanent income, 6.2 percent. The distinction between the two experiments is the value of the $\gamma$ parameter, which modulates the number of capitalist spirit consumers in the model. The higher is $\gamma$ the fewer individuals will have the additional motivation for saving. ${ }^{12}$ In this case, with a higher value for $\gamma$, the wealth distribution becomes more right skewed as measured by the Gini coefficient and by the percentage of wealth held by the top 1 percent of the wealth distribution.

From these experiments, I find that, first, wealth becomes increasingly concentrated until retirement (65 years old), as can be observed from two measures of inequality, the fraction of wealth the top 1 percent of the wealth distribution holds and the Gini coefficient measurement of inequality. Second, approximately half the skewness in the wealth distribution in this model is generated from life cycle factors which we can see by comparing table 8 with table 7 , which shows the wealth distribution for the entire population. In table 8 , wealth is roughly 50 percent less concentrated within age groups than it is for the cross section of the entire population shown in 7 . This fact is consistent with the data on variation in wealth over the life cycle.

\subsection{Wealth Accumulation with Capitalist-Spirit Preferences}

Individuals with low levels of permanent income are also typically the youngest: they save little of their income and would go into debt if they did not face a positive probability of unemployment in each period. In fact, without the low probability unemployment shock, approximately 10 to 15 percent of the households would carry debt through some part

\footnotetext{
${ }^{12}$ The relationship between $\gamma$ and the wealth distribution in a stochastic environment is not linear. This is particularly true for values of $\alpha$ larger than one.
} 
of their life cycle. As individuals progress in their careers, they receive higher levels of permanent income, and so begin to save for precautionary purposes and for retirement. If their income draws are sufficiently high, they also begin accumulating wealth for the sake of it.

The first panel in table 9 shows the ratio of wealth to permanent income ratio by age level generated by the capitalist spirit model with parameters $\alpha=1.0$ and $\gamma=\$ 150,000$. The ratio is calculated for different percentiles of the wealth/permanent income distribution. At the 99th percentile, individuals who are 65 years old have accumulated approximately 20 times their initial permanent income. These are the individuals who received one of the highest income draws in the first period and who have saved most of their income. At age 75, the wealth to permanent income ratio continues to increase. Comparing these results with the baseline precautionary saving model, we see that at the top of the permanent income distribution, 65 year old individuals have accumulated approximately 7 times their initial permanent income level. During retirement, precautionary savers run down their assets, so that by age 75 they have only twice their initial permanent income left to consume. ${ }^{13}$

The second panel of table 9 shows the ratio of wealth to permanent income by age level generated by the model with parameters $\alpha=1.7$ and $\gamma=\$ 150,000$. A similar pattern is exhibited under the new parameterization although the accumulation pattern is not quite as strong during the retirement years. The accumulation pattern for the baseline precautionary saving model is the same as in the first panel; the numbers are only re-reported for ease of comparison. The results are roughly consistent over the reported parameterizations.

\subsection{How Does the Model Compare?}

The standard model for understanding saving and consumption behavior is the precautionary saving model in either a life cycle or dynastic formulation (Carroll, 1997; Cagetti, 2003; Gourinchas and Parker, 2002). This framework models two of the most important reasons for saving: to finance retirement consumption and to protect current consumption from unexpected income shocks. Aiyagari (1994) and Carroll (1992), for example, are able to explain the saving behavior of much of the population when they include idiosyncratic labor income uncertainty, but generate considerably less wealth concentration than observed empirically. Lately, the model has been further refined by the addition of habits, uncertain future medical expenses, social security benefits, and occupational choice. The formulation of the life-cycle model that adds social insurance, realistic demographic characteristics and differences in education or human capital is able to capture the behavior of households through roughly the 70th percentile of the wealth distribution (Huggett and Ventura, 2000). It cannot account for the remainder of the wealth distribution, however, and in particular

\footnotetext{
${ }^{13}$ I assume that individuals receive retirement benefits equal to a percentage (70 percent) of their last working year's income. Thus, retirement savings only supplement their retirement benefits.
} 
the creation of large estates.

Other work extends the overlapping generations framework to a mixed dynastic framework, where households live only two periods of arbitrary length but reside within dynasties linked by intergenerational bequests and intergenerational transference of earnings ability. Some of these models, for example, De Nardi (2004), are able to explain part of the concentration of wealth by introducing social insurance which increases the number of households with zero or negative wealth when households are permitted to borrow. Castañeda, DíazGiménez, and Rios-Rull (2003) can produce most of inequality of the wealth distribution in a dynastic general equilibrium framework when they assume an income process that has a low probability extremely high income state. Their assumptions on income are not estimated from the data but calibrated to match moments of the wealth and income distribution within their model.

I report the results of four influential studies in table 10 to compare with the results presented in this paper. Each of these studies reports distributional statistics for wealth and/or earnings, including a Gini coefficient measure of inequality. The study that best approximates the U.S. wealth distribution is De Nardi (2004). She replicates some of the right skewness of the wealth distribution as a result of allowing households to borrow. Approximately 10 to 15 percent of the households in her model economy have negative or zero wealth, consistent with data on the U.S. wealth distribution, but she is not able to generate the concentration of wealth among the households who fall into the top 5 to 10 percent of the wealth distribution. The canonical models simulated in Aiyagari (1994) and Castañeda, Díaz-Giménez, and Rios-Rull (2003) in particular perform poorly in explaining wealth concentration. Huggett (1996) adds social security and demographic parameters to a life cycle model, enabling his model to explain some of the wealth concentration, although the concentration of wealth is generated by the fact that income and wealth poor individuals receive social security payments and therefore save very little many carrying debt for the majority of their lives.

Looking at the results for model with capitalist-spirit preferences reported on the last line, we can see that the model with capitalist spirit preferences does a better job of matching the data than the current literature. But, if we compare the results to the entire population represented in the SCF data in table 1, the model with capitalist spirit preferences underpredicts the share of wealth held by the percentiles of the wealth distribution. In order to more closely match the entire cross-section of data, I need to include a more realistic modeling of retirement income and saving, uncertainty regarding medical expenses and death, as well to include of profits from business ventures or stock markets (See Francis 2006). But even with these limitations, a simple modification of the life cycle model gets close to predicting the empirical wealth concentration.

The model with capitalist-spirit preferences is able to generate approximately two thirds 
of the wealth concentration, when considering the entire population, without a particularly skewed permanent income distribution or inclusion of profits from capital. Moreover, the choice of parameter values is conservative: households experience moderate growth of income and receive permanent shocks which can affect their permanent income positively by at most 10 percent in one period. In reality, high income households at age 25 likely continue to draw higher and higher permanent income levels. In addition, income from profits is undoubtedly a very important explanatory factor for large estates. The possibility of achieving a very high return on a relatively modest investment, for example, like Bill Gates' return on his investment in Microsoft, must also play a role in the skewness of the wealth distribution.

\section{Response of the Wealthy to Risk}

A model of consumption behavior with capitalist-spirit preferences has implications for how wealthy households respond to risk. The curvature of the utility function, in general, controls the consumer's attitude toward risk, while the degree of precaution is determined from the convexity of the marginal utility function. The utility function with capitalistspirit preferences has two separate curvature parameters, the parameter associated with the intraperiod utility function over consumption and the parameter associated with the intraperiod utility function over wealth. Thus the household's attitude toward risk depends on its permanent income level.

Consider the Arrow-Pratt definition of relative risk aversion,

$$
r(X)=-\frac{X u^{x x}(X)}{u^{x}(X)} .
$$

Given the capitalist-spirit utility function

$$
U\left(C_{t}, W_{t}\right)=\frac{C_{t}^{(1-\rho)}}{1-\rho}+\frac{\left(W_{t}+\gamma\right)^{(1-\alpha)}}{1-\alpha}
$$

the coefficient of relative risk aversion for gambles over consumption is

$$
r\left(C_{t}\right)=-\frac{C_{t} u^{c c}\left(C_{t}\right)}{u^{c}\left(C_{t}\right)}=\rho
$$

which is constant with increases in consumption, as in the canonical utility function. For households with low permanent income draws, $\rho$ will be the curvature parameter controlling risk aversion.

Risk aversion with respect to gambles over wealth, is given by

$$
r_{r}\left(W_{t}\right)=\frac{\alpha W_{t}}{\left(W_{t}+\gamma\right)}
$$


so that risk aversion with respect to gambles over wealth approaches $\alpha$ asymptotically, or $W_{t} \rightarrow \infty, r_{r}(W, u) \rightarrow \alpha$. The risk aversion of very wealthy individuals is dominated by $\alpha$, while for moderately wealthy individuals the coefficient of risk aversion is a combination of $\rho$ and $\alpha$ that asymptotes to $\alpha$ as wealth grows. Thus as wealth increases, risk aversion decreases, so long as $\rho>\alpha$.

The model with capitalist-spirit preference has two features that allow it to explain the relative riskiness of wealthy individual's portfolios. First, risk aversion declines with wealth which implies that the wealthy should hold a larger share of their wealth in riskier assets such as securities. Second, as permanent income grows, individuals consume an increasingly smaller fraction of their income.

Although we cannot determine the level of risk aversion analytically in our model since it will be a weighted average of risk aversion over consumption and wealth gambles, we can simulate the level of risk aversion numerically for different levels of permanent income along the optimal path for consumption. The empirical measure of relative risk aversion is determined from the value function as

$$
r_{r}\left(W_{t}\right)=\frac{-V^{w w}\left(W_{t}, P_{t}\right)}{V^{w}\left(W_{t}, P_{t}\right)} W_{t} .
$$

In order to understand how the risk profile of capitalist spirit consumers is changing as their wealth increases, we can separate out the factors causing contributing to the change in the risk behavior of low income consumers as their income grows. Intuitively, a convex combination of the elasticity of the marginal utility functions determines the degree of risk aversion. Differentiating the Bellman equation with respect to current wealth gives:

$$
\begin{array}{r}
V^{w}\left(W_{t}, P_{t}\right)=u^{w}\left(C_{t}, W_{t}\right) \\
V^{w w}\left(W_{t}, P_{t}\right)=u^{w w}\left(C_{t}, W_{t}\right) C^{w}\left(W_{t}, P_{t}\right) .
\end{array}
$$

This can be expressed this as

$$
\frac{V^{w w}\left(W_{t}, P_{t}\right)}{V^{w}\left(W_{t}, P_{t}\right)}=\frac{u^{w w}\left(C_{t}, W_{t}\right)}{u^{w}\left(C_{t}, W_{t}\right)} C^{w}\left(W_{t}, P_{t}\right)
$$

or, to make it more comparable to the Arrow Pratt definition of relative risk aversion, we can multiply through by negative wealth to give

$$
\frac{-V^{w w}\left(W_{t}, P_{t}\right)}{V^{w}\left(W_{t}, P_{t}\right)} W_{t}=-\frac{u^{w w}\left(C_{t}, W_{t}\right)}{u^{w}\left(C_{t}, W_{t}\right)} C\left(W_{t}, P_{t}\right) * \frac{W_{t} C^{w}\left(W_{t}, P_{t}\right)}{C\left(W_{t}, P_{t}\right)}
$$

The first term on the right hand side is the usual Arrow Pratt coefficient of relative risk aversion: $-\frac{u^{w w}\left(C_{t}, W_{t}\right)}{u^{w}\left(C_{t}, W_{t}\right)} C\left(W_{t}, P_{t}\right)$. The Arrow Pratt coefficient asymptotes to $\alpha$ as income (and therefore wealth) approaches $\infty$ but is exactly equal to $\rho$ when income is very low, 
as in the baseline precautionary saving model. The second term, $\frac{W C^{w}(W, P)}{C(W, P)}$, expresses the marginal propensity to consume out of increases in wealth or the elasticity of the marginal utility function. It demonstrates intuitively the way in which individuals become less risk averse as their wealth rises: as wealth rises, the marginal propensity to consume out of the increase in wealth falls and the ratio of wealth to consumption grows until the entire equation is dominated by the elasticity of the marginal utility function for wealth.

Table 11 shows this empirical 'risk factor'for households at different values of permanent income in the capitalist spirit and baseline precautionary saving model. ${ }^{14}$ The parameter values used for this calculation are $\alpha=1.0$ and $\gamma=\$ 150,000$. In the baseline precautionary saving model, as permanent income rises, the marginal propensity to consume out of increases in income rises quickly to asymptote at approximately 1 . For consumers with capitalist-spirit preferences, as permanent income rises, their marginal propensity to consume rises at a slower rate than the precautionary savers and asymptotes at approximately 0.8. When the preference for risk is increasing in the level of wealth (or wealth to permanent income as we report here), the proportion of wealth invested in a risky asset should increase relative to the proportion that is invested in the risk free asset. But, in the model I present, there is no second risky asset. So we are left with only the implication that lower risk aversion for capitalist-spirit consumers will result in higher equity percentages in their portfolios. See Ait-Sahalia, Parker, and Yogo (2004) for a similar implication when individuals can choose to consume basic or luxury goods. By contrast, for individuals with a standard CRRA utility function, willingness to invest in risky assets will be determined by the coefficient of relative risk aversion, $\rho$, which is constant and independent of wealth.

Figure 2 displays the information contained in table 11 graphically. The dotted curve represents the risk attitude of the precautionary saver while the bottom smooth curve represents the risk attitude of the capitalist spirit consumer. From this figure, we can see that the attitude toward risk (measured here as the marginal propensity to consume times the ratio of wealth to consumption) for the precautionary savers increases quickly and asymptotes to 1.0, whereas for capitalist spirit consumers it increases at a much slower rate and asymptotes to 0.8 , so that the curve depicting the risk attitude of the capitalist spirit consumer always lies below that of the precautionary saver. ${ }^{15}$

Figure 2 about here

The model with capitalist-spirit preferences thus provides a means for risk aversion

\footnotetext{
${ }^{14}$ The values of permanent income correspond to the percentiles in the first period, before individuals experience any type of income shocks.

${ }^{15}$ The bumpiness at the low end of wealth holdings $(x-a x i s)$ of the capitalist spirit MPC function is due to the fact that in the capitalist spirit model the MPC is also a function of permanent income. In order to use a two-dimensional graph, permanent income is held constant and wealth holding is permitted to vary in a realistic fashion. The result of this expository simplification is the flat part and the initial bump in the MPC function.
} 
to differ across individuals based on their income level, without assuming heterogeneous discount rates or other idiosyncratic preferences. Individuals with high income draws will display lower risk aversion than those with low draws. These wealthier individuals will hold portfolios with riskier profiles than the relatively poor. Moreover, relative risk aversion in a model with capitalist spirit preferences is no longer tied to the intertemporal elasticity of substitution as it is in the baseline precautionary saving model. In order to further investigate the implication of capitalist spirit preferences for relative portfolio composition, or its impact on the equity premium puzzle, I would need to examine the case with a risky and a risk free asset. This exercise is left for a future paper.

\section{Conclusion}

I demonstrate that including a direct, additively separable, preference for wealth in the utility function provides a mechanism for high income households to continue accumulating assets even when they have saved sufficiently for retirement and precautionary purposes. In this way, the model with capitalist-spirit preferences can explain several features of the data, in particular, the concentration of wealth, the increasing concentration of wealth as individuals age, absence of retiree de-cumulation and increasing risk tolerance with wealth, all with a fairly simply change in preferences.

Moreover, capitalist-spirit preferences provide an explanation for disproportional wealth concentration (relative to income) without relying on bequest motives. Although including intergenerational transfers in models of saving behavior has been the standard response for explaining the excess skewness of the wealth distribution, the empirical evidence for bequests is mixed at best. For example, according to altruistic bequest theory, children with low permanent income should receive more transfer income from their parents than children with high permanent income. Yet empirical studies demonstrate either the opposite or that wealth is shared equally among children. The advantage of capitalist-spirit preferences is that they provide a parsimonious means for capturing the desire to accumulate wealth regardless of life status, e.g., for childless families as well as those with children, that is also able to account for the fact that there are many motivations for bequests: altruistic, egoistic, or accidental. Bequest motives may indeed be active across some subset of the wealthy population. The model with capitalist-spirit preferences can capture these motives too, as capitalist-spirit preferences effectively act as a bequest motive.

This paper is the first to present additive capitalist-spirit preferences in a fully developed life cycle model. The inclusion of capitalist-spirit preferences in this simple life cycle model, however, do not replicate all of the skewness of the wealth distribution. In order to explain the creation of massive estates observed in the data, the model needs to incorporate other factors such as capital earnings especially from entrepreneurial ventures. These ideas are 
left for a future paper.

\section{$9 \quad$ Appendix}

\subsection{Tables and Figures}

Table 1: Percent of Wealth held by percentiles of the wealth distribution.

\begin{tabular}{lccccc}
\hline \hline Percentile & $\mathbf{1 9 8 9}$ & $\mathbf{1 9 9 2}$ & $\mathbf{1 9 9 5}$ & $\mathbf{1 9 9 8}$ & $\mathbf{2 0 0 1}$ \\
\hline Top 1\% & 30.3 & 30.2 & 34.6 & 33.9 & 32.7 \\
Top 5\% & 54.4 & 54.6 & 55.9 & 57.2 & 57.7 \\
Top 10\% & 67.4 & 67.2 & 67.8 & 68.6 & 69.8 \\
Top 50\% & 97.3 & 96.9 & 96.4 & 97.0 & 97.2 \\
Bottom 50\% & 2.7 & 3.3 & 3.6 & 3.0 & 2.8 \\
Gini & 0.78 & 0.78 & 0.78 & 0.79 & 0.80 \\
\hline
\end{tabular}

Note: Survey of Consumer Finances (SCF) data from reported years. Wealth refers to Net Worth calculated from data on assets and debt reported in the SCF. From Kennickell (2003), table 15 and Kennickell (2006), table 4.

Table 2: Percent of Income held by percentiles of the income distribution

\begin{tabular}{|c|c|c|}
\hline 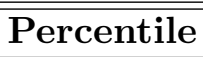 & 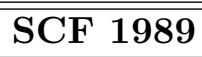 & 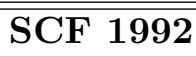 \\
\hline Top 1\% & 16.9 & 18.6 \\
\hline Top 5\% & 31.7 & 34.5 \\
\hline Top $10 \%$ & 42.3 & 45.2 \\
\hline Top $20 \%$ & 57.2 & 59.9 \\
\hline Gini & 0.54 & 0.57 \\
\hline
\end{tabular}

Note: The percent of income reported here is normal income reported in the Survey of Consumer Finances. Normal Income is the empirical equivalent of permanent income. Taken from Quadrini 1999. 
Table 3: Main Reasons for Saving

\begin{tabular}{lllll}
\hline \hline & $\mathbf{1 9 9 2}$ & $\mathbf{1 9 9 5}$ & $\mathbf{1 9 9 8}$ & $\mathbf{2 0 0 1}$ \\
\hline Retirement & 19.4 & 23.7 & 33.0 & 32.1 \\
\hline Liquidity & 33.9 & 33.0 & 29.8 & 31.2 \\
Education & 9.1 & 10.8 & 11.0 & 10.9 \\
Housing & 4.0 & 5.1 & 4.4 & 4.2 \\
\hline For Family & 2.6 & 2.7 & 4.1 & 5.1 \\
Purchases & 9.7 & 12.8 & 9.7 & 9.5 \\
Investments & 7.6 & 4.2 & 2.0 & 1.0 \\
Do not Save & 12.0 & 6.8 & 4.9 & 4.9 \\
\hline
\end{tabular}

Note: This table is from Kennickell 2003 and reports Survey of Consumer Finances survey responses for various years.

Table 4: Description of Permanent Income Distribution in Simulations

\begin{tabular}{lllllll}
\hline \hline Age & $\mathbf{1} \%$ & $\mathbf{5 \%}$ & $\mathbf{1 0 \%}$ & $\mathbf{2 0 \%}$ & $\mathbf{4 0 \%}$ & Gini \\
\hline $\mathbf{2 5}$ & 6.2 & 19.9 & 31.5 & 48.3 & 71.0 & 0.43 \\
\hline
\end{tabular}

Note: Calibration assumptions for individual income draws in the first period.

Table 5: Fixed Parameters

\begin{tabular}{llr}
\hline \hline Parameter & Description & Value \\
\hline$\beta$ & discount factor & 0.96 \\
$\rho$ & coefficient of risk aversion & 2.0 \\
$\sigma_{\Psi}$ & SD of permanent income shock & 0.1 \\
$\sigma_{y}$ & SD of initial log income distribution & 0.83 \\
$R$ & risk free interest rate & 1.03 \\
$T$ & life length & $55 \mathrm{yrs}$ \\
$T_{r}$ & retirement begins & $40(=65$ yo in real yrs $)$ \\
$p$ & probability of unemployment & 0.005 \\
$G$ & growth rate of perm income (level) & 1.03 \\
\hline
\end{tabular}

Note: Fixed calibration assumptions used in all of the simulations, except where noted. 
Table 6: Calibrated Capitalist-Spirit Parameters

\begin{tabular}{lll}
\hline \hline Parameter & Description & Value \\
\hline$\alpha$ & coeff of risk aversion on $W_{t}$ & $1.0 ; 1.7$ \\
$\gamma$ & accumulation modifying parameter & 150,$000 ; 750,000 ; 10,000,000$ \\
\hline
\end{tabular}

Note: Values of capitalist-spirit parameters for all simulations.

Table 7: Cross Sectional Distribution of Wealth for Population

\begin{tabular}{llrrrrrr}
\hline \hline Experiment & $\alpha$ & $\gamma$ & $\mathbf{1 \%}$ & $\mathbf{5 \%}$ & $\mathbf{1 0 \%}$ & $\mathbf{2 0 \%}$ & Gini \\
\hline SCF 1998, 25-65 & - & - & 14 & 38 & 53 & 72 & 0.67 \\
\hline PS model & - & - & 5.5 & 19.2 & 31.8 & 51.1 & 0.45 \\
KS model & 1.0 & 150,000 & 11.4 & 31.4 & 46.0 & 63.1 & 0.62 \\
KS model & 1.0 & 750,000 & 14.6 & 35.4 & 56.1 & 68.3 & 0.63 \\
KS model & 1.0 & $10,000,000$ & 4.2 & 15.1 & 32.1 & 53.0 & 0.44 \\
KS model & 1.7 & 150,000 & 12.0 & 32.5 & 48.1 & 68.3 & 0.61 \\
KS model & 1.7 & 750,000 & 14.1 & 36.6 & 51.0 & 69.5 & 0.65 \\
KS model & 1.7 & $10,000,000$ & 5.6 & 21.1 & 34.8 & 54.7 & 0.45
\end{tabular}

Note: PS refers to precautionary saving model with the usual preferences, KS refers to model with capitalist-spirit preferences, SCF refers to the Survey of Consumer Finances.

Table 8: Wealth holdings by percentile by Age Group

\begin{tabular}{llllllllllll}
\hline \hline & \multicolumn{3}{l}{ Capitalist-Spirit Model } & \multicolumn{4}{c}{ Precautionary Saving Model } \\
& Age & $\mathbf{1 \%}$ & $\mathbf{5 \%}$ & $\mathbf{1 0 \%}$ & $\mathbf{2 0 \%}$ & Gini & $\mathbf{1 \%}$ & $\mathbf{5 \%}$ & $\mathbf{1 0 \%}$ & $\mathbf{2 0 \%}$ & Gini \\
\hline Panel 1 & $\mathbf{3 0}$ & 6.9 & 21.6 & 33.9 & 51.3 & 0.43 & 1.3 & 5.9 & 11.5 & 22.4 & 0.10 \\
$\alpha=1.0$ & $\mathbf{4 5}$ & 7.5 & 23.3 & 36.2 & 54.0 & 0.46 & 1.9 & 7.8 & 14.4 & 26.5 & 0.13 \\
$\gamma=\$ 150,000$ & $\mathbf{6 5}$ & 8.5 & 26.0 & 40.2 & 59.5 & 0.53 & 2.6 & 10.0 & 17.7 & 31.1 & 0.19 \\
& $\mathbf{8 0}$ & 8.5 & 25.8 & 40.2 & 59.4 & 0.52 & 3.0 & 11.5 & 19.9 & 33.8 & 0.23 \\
\hline Panel 2 & $\mathbf{3 0}$ & 8.8 & 25.5 & 38.5 & 56.0 & 0.51 & 1.3 & 5.9 & 11.5 & 22.4 & 0.10 \\
$\alpha=1.0$ & $\mathbf{4 5}$ & 10.1 & 27.9 & 41.6 & 59.8 & 0.55 & 1.9 & 7.8 & 14.4 & 26.5 & 0.13 \\
$\gamma=\$ 750,000$ & $\mathbf{6 5}$ & 10.9 & 30.3 & 44.0 & 62.6 & 0.58 & 2.6 & 10.0 & 17.7 & 31.1 & 0.19 \\
& $\mathbf{8 0}$ & 10.9 & 30.5 & 44.1 & 62.1 & 0.57 & 3.0 & 11.5 & 19.9 & 33.8 & 0.23 \\
\hline
\end{tabular}

Note: Percentage of wealth held by selected percentiles of the wealth distribution in the simulated model with capitalist-spirit preferences. Percentage of wealth held by percentiles of the wealth distribution in a simulated model with only precautionary saving motives are shown for comparison. Parameters values for the model with capitalist-spirit preferences are shown in the first column. 
Table 9: Wealth to Permanent Income Level by Age in Model

\begin{tabular}{llllll}
\hline \hline & Percentile & $\begin{array}{l}\text { KS Model } \\
\text { Age 65 }\end{array}$ & $\begin{array}{l}\text { KS Model } \\
\text { Age 75 }\end{array}$ & $\begin{array}{l}\text { PS Model } \\
\text { Age 65 }\end{array}$ & $\begin{array}{l}\text { PS Model } \\
\text { Age 75 }\end{array}$ \\
\hline Panel 1 & Top 1\% & 23.5 & 24.8 & 7.2 & 2.1 \\
$\alpha=1.0$ & Top 5\% & 21.3 & 24.6 & 6.9 & 2.0 \\
$\gamma=\$ 150,000$ & Top 10\% & 18.1 & 19.2 & 5.5 & 1.1 \\
\hline Panel 2 & Top 1\% & 24.1 & 25.4 & 7.2 & 2.1 \\
$\alpha=1.7$ & Top 5\% & 22.6 & 24.2 & 6.9 & 2.0 \\
$\gamma=\$ 150,000$ & Top 10\% & 21.4 & 23.1 & 5.5 & 1.1 \\
\hline
\end{tabular}

Note: The ratios of wealth to permanent income for selected percentiles of the wealth distribution are shown for both the model with capitalist-spirit preferences (KS) and the baseline precautionary saving model (PS) for selected ages. Retirement occurs at age 65. Parameter values for the KS model are shown in the first column.

Table 10: Comparison of Recent Studies of the Wealth Distribution

\begin{tabular}{lllllll}
\hline \hline Study & Model & Series & Top & Top & Bottom & Gini \\
\hline & & & $1 \%$ & $5 \%$ & $40 \%$ & Coeff \\
\hline Aiyagari (1994) & Dynastic & Earnings & 6.8 & 7.5 & 32.5 & 0.10 \\
& & Wealth & 3.2 & 13.1 & 14.9 & 0.38 \\
\hline Castañeda et al (2003) & Dynastic & Earnings & 2.0 & 10.1 & 20.6 & 0.30 \\
& & Wealth & 1.7 & 7.9 & 32.0 & 0.13 \\
\hline Huggett (1996) & Life Cycle & Earnings & 13.6 & 22.6 & 9.8 & 0.42 \\
& & Wealth & 11.1 & 33.8 & 0.0 & 0.74 \\
\hline De Nardi (2004) & Life Cycle w/ Bequests & Earnings & $\mathrm{n} / \mathrm{a}$ & $\mathrm{n} / \mathrm{a}$ & $\mathrm{n} / \mathrm{a}$ & $\mathrm{n} / \mathrm{a}$ \\
& & Wealth & 15.0 & 38.0 & 1.0 & 0.61 \\
\hline Francis (2007) & Life Cycle w/ Cap Spirit & Earnings & 6.2 & 19.9 & $\mathrm{n} / \mathrm{a}$ & 0.43 \\
& & Wealth & 14.1 & 36.6 & $\mathrm{n} / \mathrm{a}$ & 0.65 \\
\hline Note: Data
\end{tabular}

Note: Data taken from cited articles.

Table 11: Risk Factor Comparison at Different Levels of Permanent Income

\begin{tabular}{cllll}
\hline \hline Percentile & $\begin{array}{l}\text { KS Model } \\
\text { Perm. Inc. }\end{array}$ & $\begin{array}{l}\text { KS Model } \\
\text { Risk Factor }\end{array}$ & $\begin{array}{l}\text { PS Model } \\
\text { Perm. Inc. }\end{array}$ & $\begin{array}{l}\text { PS Model } \\
\text { Risk Factor }\end{array}$ \\
\hline 10th & $\$ 7,720$ & 0.3072 & $\$ 7,720$ & 0.6943 \\
50th & $\$ 21,784$ & 0.4918 & $\$ 21,784$ & 0.8455 \\
75th & $\$ 38,160$ & 0.5717 & $\$ 38,160$ & 0.9033 \\
90th & $\$ 62,676$ & 0.7035 & $\$ 62,676$ & 0.9618 \\
95th & $\$ 85,584$ & 0.7510 & $\$ 85,584$ & 0.9899 \\
99th & $\$ 344,242$ & 0.7912 & $\$ 344,242$ & 0.9999 \\
\hline
\end{tabular}

Note: Comparison of risk coefficients at selected percentiles of the wealth distribution for both the model with capitalist-spirit preferences (KS) and the baseline precautionary saving model (PS). Perm. Inc. refers to level of permanent income. 


\subsection{Properties of the Utility Function}

\subsubsection{Marginal Utility}

In order to understand how capitalist-spirit preferences capture the desire for wealth, in figure 3, I compare the marginal utility of wealth with the marginal utility of consumption. The marginal utility of consumption, in this model, is decreasing monotonic as in the baseline precautionary saving model. However, the marginal utility of wealth will not necessarily decrease monotonically due to the presence of $\gamma$.

Figure 3 about here

In figure 3 , the steeply sloped dashed line is the marginal utility of consumption. The marginal utility of an additional unit of consumption declines quickly as consumption increases. In contrast, the smooth line is the marginal utility of an additional unit of wealth for $\alpha=1.0^{16}$, which declines much more slowly as wealth increases. The dotted line at the very bottom of the figure, is the marginal utility of an additional unit of wealth for $\alpha=1.7$; in this case the marginal utility of wealth declines at a slower rate than the marginal utility of consumption but faster than the case when $\alpha=1.0$. I provide this example as a comparison and to highlight the mechanism by which capitalist-spirit preferences, within the parameter ranges discussed in this paper, motivate individuals to continue accumulating wealth.

\subsection{Consumption and Wealth Shares}

For the class of utility functions used in this paper,

$$
U\left(C_{t}, W_{t}\right)=u\left(c_{t}\right)+v\left(w_{t}\right)=\frac{C_{t}^{1-\rho}}{1-\rho}+\frac{\left(W_{t}+\gamma\right)^{1-\alpha}}{1-\alpha}
$$

wealth is a luxury good if $\gamma>0$.

Proposition 1 For the given utility function with $\gamma>0$ and $\rho>\alpha>$

$$
\begin{aligned}
& \lim _{Y \rightarrow \infty} \frac{C_{t}}{Y_{t}}=0 \\
& \lim _{Y \rightarrow \infty} \frac{S_{t}}{Y_{t}}=1
\end{aligned}
$$

where $S$ is saving out of current income, not accumulated wealth, which in general will be larger than $Y$.

\footnotetext{
${ }^{16} \mathrm{I}$ do not report $\gamma$ here because its scale is different than the scale used above as this figure is only for exposition.
} 
Proof. Let $\hat{S}_{t}=S_{t}+\gamma$, then current income is divided between current consumption and current saving or $Y_{t}=C_{t}+\hat{S}_{t}$.

The intratemporal first order condition is: $C^{-\rho}=\hat{S}_{t}^{-\alpha}$ so that $\hat{S}_{t}=C^{\frac{\rho}{\alpha}}$. Then

$$
\frac{C_{t}}{Y_{t}}=\frac{C_{t}}{C_{t}+\hat{S}_{t}}=\frac{C_{t}}{C_{t}+C^{\alpha}}
$$

or

$$
\frac{C_{t}}{Y_{t}}=\frac{1}{1+C^{\frac{\rho}{\alpha}-1}}
$$

Thus, as $Y \rightarrow \infty$, either $C \rightarrow \infty$, in which case $\frac{C_{t}}{Y_{t}} \rightarrow 0$, since $\alpha<\rho$, or $C$ is bounded in which case $\frac{C_{t}}{Y_{t}} \rightarrow 0$ remains true.

Similarly for the wealth share. From the intratemporal first order condition, $C^{-\rho}=$ $\hat{S}_{t}^{-\alpha}$, we also have $C_{t}=\hat{S}^{\frac{\alpha}{\rho}}$. Thus

$$
\frac{\hat{S}_{t}}{Y_{t}}=\frac{\hat{S}_{t}}{C_{t}+\hat{S}_{t}}=\frac{1}{1+\hat{S}_{t}^{\frac{\alpha}{\rho}-1}}
$$

So if $\hat{S} \rightarrow \infty$ as $Y \rightarrow \infty$, then $\frac{\hat{S}}{Y} \rightarrow 1$.

\subsection{Coefficient of Relative Risk Aversion and Intertemporal Substitutabil- ity}

Consider the Euler equation for consumption. Substituting from the utility function,

$$
C_{t}^{-\rho}=R \beta\left[\left(W_{t+1}+\gamma\right)^{-\alpha}+C_{t+1}^{-\rho}\right]
$$

In this context, when there is perfect certainty, consumption is sensitive to the difference between the interest rate and the rate of time preference. In the case without capitalist

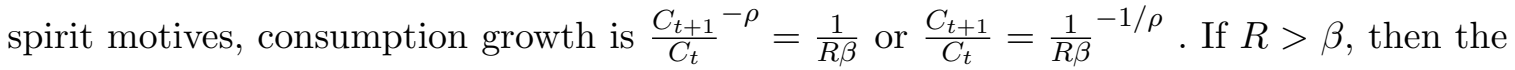
individual will have an increasing consumption profile, preferring to consume less today and more tomorrow.

In the case with capitalist spirit motives, there is an additional term. In the perfect certainty case we can write: $C_{t}^{-\rho}-R \beta C_{t+1}^{-\rho}=R \beta\left(W_{t+1}+\gamma\right)^{-\alpha}$. If $R \beta=1$, then $C_{t}^{-\rho}-$ $C_{t+1}^{-\rho}=\left(W_{t+1}+\gamma\right)^{-\alpha}$, and the difference between the marginal utility of consumption between periods is equal to the marginal utility of wealth. Additionally, the fact that wealth generates direct utility makes the effect of the interest rate on current consumption even stronger because decreasing consumption in period $t$ by a small amount not only increases the possibility of future consumption but also increases utility through the increase in wealth that it generates. 


\subsection{Concavity}

Mathematical properties of capitalist-spirit preferences. First note the Hessian matrix for $u(c, w)$

$$
D^{2} u(c, w)=\left(\begin{array}{cc}
\frac{\partial^{2} u}{\partial c^{2}} & \frac{\partial^{2} u}{\partial c \partial w} \\
\frac{\partial^{2} u}{\partial w \partial c} & \frac{\partial^{2} u}{\partial w^{2}}
\end{array}\right)
$$

Proposition $2 u(c, w)$ is a concave function if and only if its Hessian is negative semidefinite for all $(c, w) \in R^{2}$

Proof. 1. We need $u_{c c}<0$. For the function we have: $-\rho C_{t}^{-\rho-1}<0$

2. We need $u_{c c} u_{w w}-\left(u_{c w}\right)^{2}>0$. For the function we have: $\rho \alpha C_{t}^{-\rho-1}\left(\alpha\left(W_{t}+\gamma\right)^{-\alpha-1}\right)>0$

The function $u(c, w)$ satisfies the conditions for negative definiteness, therefore it is a concave function

\subsection{Simulation Technique}

To solve the model, I apply the method proposed by Deaton (1991) and elaborated by Carroll (2002). ${ }^{17}$ The technique involves iteration on the Euler equation to find the optimal consumption profile given the initial level of assets and permanent income. The method works directly from the Euler equation, where the value function must be satisfied by the solution in every period, to compute the optimal policy function through backward iterations from an initial guess of last period consumption. since the consumer might choose to die holding assets, as an optimal choice, last period's consumption is not simply the remaining assets, as in the typical life cycle problem where $T$ is less than infinity. Instead, the last period's problem is solved in the same manner as the infinite horizon problem.

There are several steps involved in solving this problem. These are:

1. Choose a functional form for the utility function

2. Discretize the state and control variables: create a grid of points for the state variables $W_{t}, P_{t}$.

3. Beginning with the last period, solve (numerically) the consumer's problem backwards to find the optimal profile for consumption and therefore asset holdings

4. Given the solved policy function for the grid points, do linear interpolation between grid points to generate a smooth policy function

5. Evaluate the resulting policy function

\footnotetext{
${ }^{17}$ This is sometimes called a projection method. See Adda and Cooper (2003)
} 
6. Simulate consumption profiles for a large set of individuals

\section{References}

Adda, J., Cooper, R., 2003. Dynamic Economics. Quantitative Methods and Applications. MIT Press, Cambridge, MA.

Ait-Sahalia, Y., Parker, J., Yogo, M., 2004. Luxury goods and the equity premium. Journal of Finance 59(6), 2959-3004.

Aiyagari, S., 1994. Uninsured idiosyncratic risk and aggregate saving. Quarterly Journal of Economics 109, 659-684.

Bakshi, G., Chen, Z., 1996. The spirit of capitalism and stock market prices. American Economic Review 86, 133-57.

Banks, J., Blundell, R., Smith, J., 2000. Wealth inequality in the united states and great britain. The Institute for Fiscal Studies WP 00/20.

Brittain, J., 1978. Inheritence and the inequality of material wealth. The Brookings Institution, Washington D.C.

Cagetti, M., 2003. Wealth accumulation over the life cycle and precautionary saving. Journal of Business and Economic Statistics 21, 339-353.

Cagetti, M., De Nardi, M., 2006. Entrepreneurship, frictions and wealth. Journal of Political Economy 106, 835-870.

Carroll, C., 1992. The buffer stock theory of saving: Some macroeconomic evidence. Brookings Papers on Economic Activity 2, 61-156.

Carroll, C., 1997. Buffer stock saving and the life cycle/permanent income hypothesis. The Quarterly Journal of Economics 112 (1), 1-56.

Carroll, C., 2000. Why do the rich save so much? In: Slemrod, J. B. (Ed.), Does Atlas Shrug? The Economic Consequences of Taxing the Rich. Harvard University Press, Cambridge.

Carroll, C., 2002. Portfolios of the rich. In: Household Portfolios: Theory and Evidence. MIT Press, Cambridge.

Carroll, C., Samwick, A., 1997. The nature of precautionary wealth. Journal of Monetary Economics 40, 41-71. 
Castañeda, A., Díaz-Giménez, J., Rios-Rull, J., 2003. Accounting for U.S. earnings and wealth inequality. Journal of Political Economy 111, 818-858.

Cole, H., Malaith, G., Postlewaite, A., 1992. Social norms, saving behavior and growth. Journal of Political Economy 100, 1092-1125.

Danziger, S., van der Graag, J., Smolensky, E., Taussig, M., 1983. The life cycle hypothesis and the consumption behavior of the elderly. Journal of Post Keynsian Economics 5, $208-227$.

De Nardi, M., 2004. Wealth and intergenerational links. Review of Economic Studies 71, $743-768$.

Deaton, A., 1991. Saving and liquidity constraints. Econometrica 59, 1221-1248.

Diaz, A., Quadrini, V., Rios-Rull, J., 1997. Dimensions of inequality: Facts on the U.S. distributions of earnings, income and wealth. Federal Reserve Bank of Minneapolis Quarterly Review 21, 3-21.

Dynan, K., Skinner, J., Zeldes, S., 2004. Do the rich save more? Journal of Political Economy 112, 397-444.

Francis, J., 2006. Entrepreneurship and the capitalist spiritManuscript. Fordham University.

Frank, R., 1985. Choosing the Right Pond: Human Behavior and the Quest for Status. Oxford University Press, New York: New York.

Friedman, M., 1957. A Theory of the Consumption Function. Princeton University Press, Princeton, NJ.

Fuster, L., 2000. Capital accumulation in an economy with dynasties and uncertain lifetimes. Review of Economic Dynamics 3, 650-674.

Geary, R., 1949-50. A note on: A constant utility index of the cost of living. Review of Economic Studies 18, 65-66.

Gourinchas, P., Parker, J., 2002. Consumption over the life cycle. Econometrica 70 (1), $47-89$.

Hendricks, L., 2002. Intended and accidental bequests in a life cycle economy, working Paper. Department of Economics, Arizona State University.

Hendricks, L., 2004. Accounting for patterns of wealth inequality, working Paper. Department of Economics, Iowa State University. 
Huggett, M., 1996. Wealth distribution in life cycle economies. Journal of Monetary Economics 38, 469-494.

Huggett, M., Ventura, G., 2000. Understanding why high income households save more than low income households. Journal of Monetary Economics 45, 361-397.

Huggett, M., Ventura, G., Yaron, A., 2003. Human capital and earnings distribution dynamics. NBER working paper (9366).

Hurd, M., 1986. Savings and bequests. NBER working paper 1826.

Kennickell, A., 2003. A rolling tide: Changes in the distribution of wealth in the U.S., 1989-2001. Survey of Consumer Finances, Working Paper.

Kennickell, A., 2006. Currents and undercurrents: Changes in the distribution of wealth, 1989-2004. Finance and Economics Discussion Series, Federal Reserve Board 13.

Kotlikoff, L., Summers, L., 1981. The role of intergenerational transfers in aggregate capital formation. Journal of Political Economy 89, 706-732.

Kurz, M., 1968. Optimal economic growth and wealth effects. International Economic Review $9,348-57$.

Luo, Y., Young, E., April 2003. The wealth distribution and the demand for statusWorking Paper. Princeton University.

Menchik, P., David, M., 1983. Income distribution, lifetime savings, and bequests. American Economic Review 73, 672-690.

Quadrini, V., 1999. The importance of entrepreneurship for wealth concentrationWorking paper. Duke University.

Reiter, M., 2004. Do the rich save too much? How to explain the top tail of the wealth distributionWorking paper. Universitat Pompeu Fabra.

Smith, A., 1776. The Wealth of Nations. Modern Library, New York, NY, 1930 edition.

Smith, W., 1999. Risk, the spirit of capitalism and growth: The implications of a preference for capital. Journal of Macroeconomics 21, 241-262.

Stone, J., 1954. Linear expenditure systems and demand analysis: An application to the pattern of British demand. Economic Journal 64, 511-527.

Weber, M., 1905. The Protestant Ethic and the Spirit of Capitalism. Charles Scribners' and Sons, 1958 translated edition. 
Zou, H., 1995. The spirit of capitalism and saving behavior. Journal of Economic Behavior and Organization 28, 131-143. 
Figure 1: Wealth to Permanent Income Ratios over Life Cycle for Median and TopDecile Households
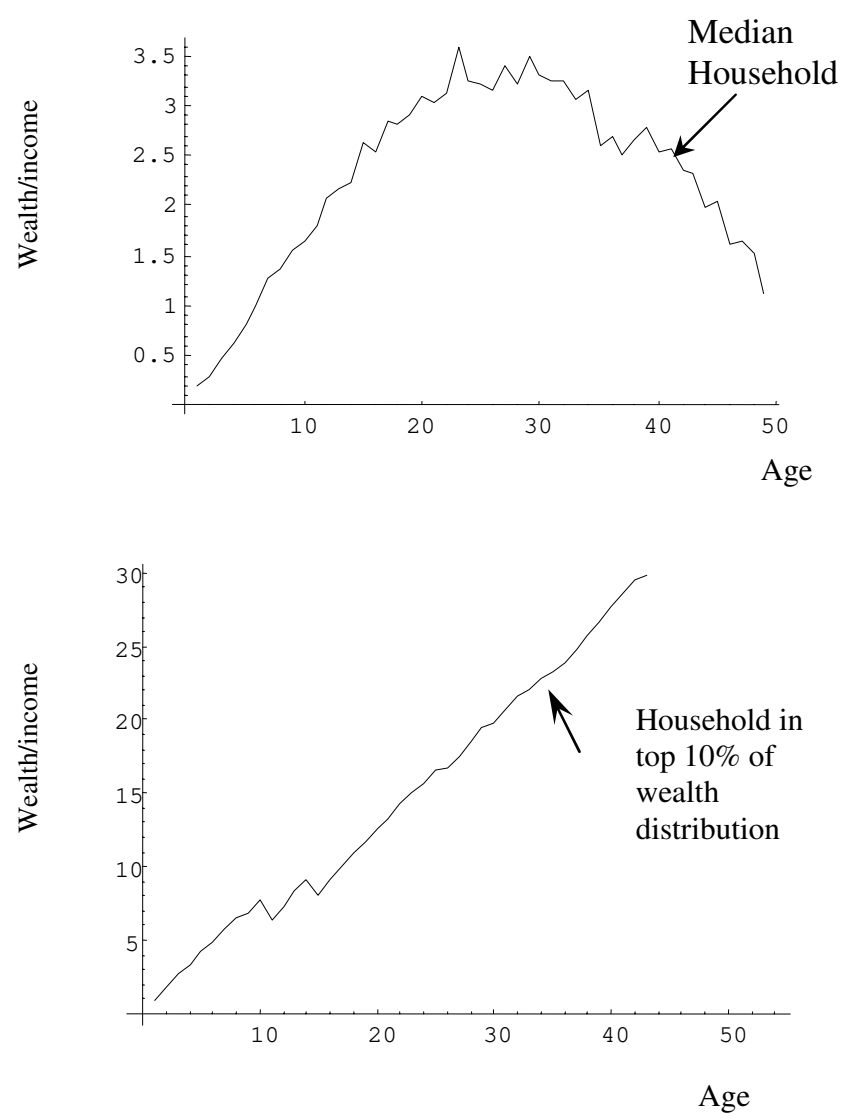
Figure 2: Comparative Risk Behavior in Baseline and Capitalist Spirit Model.

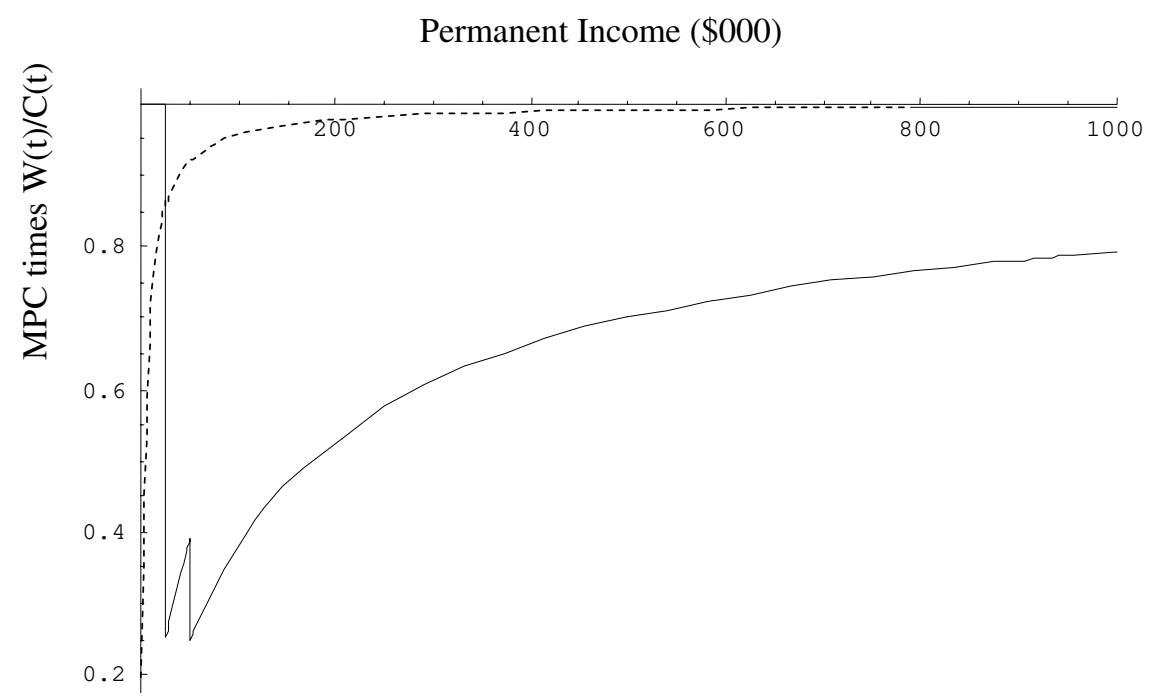

Note: The dotted line is without capitalist-spirit preferences, the solid line is with capitalist-spirit preferences. Permanent income levels are reported in the thousands of dollars. 
Figure 3: Marginal Utility of Wealth versus Marginal Utility of Consumption

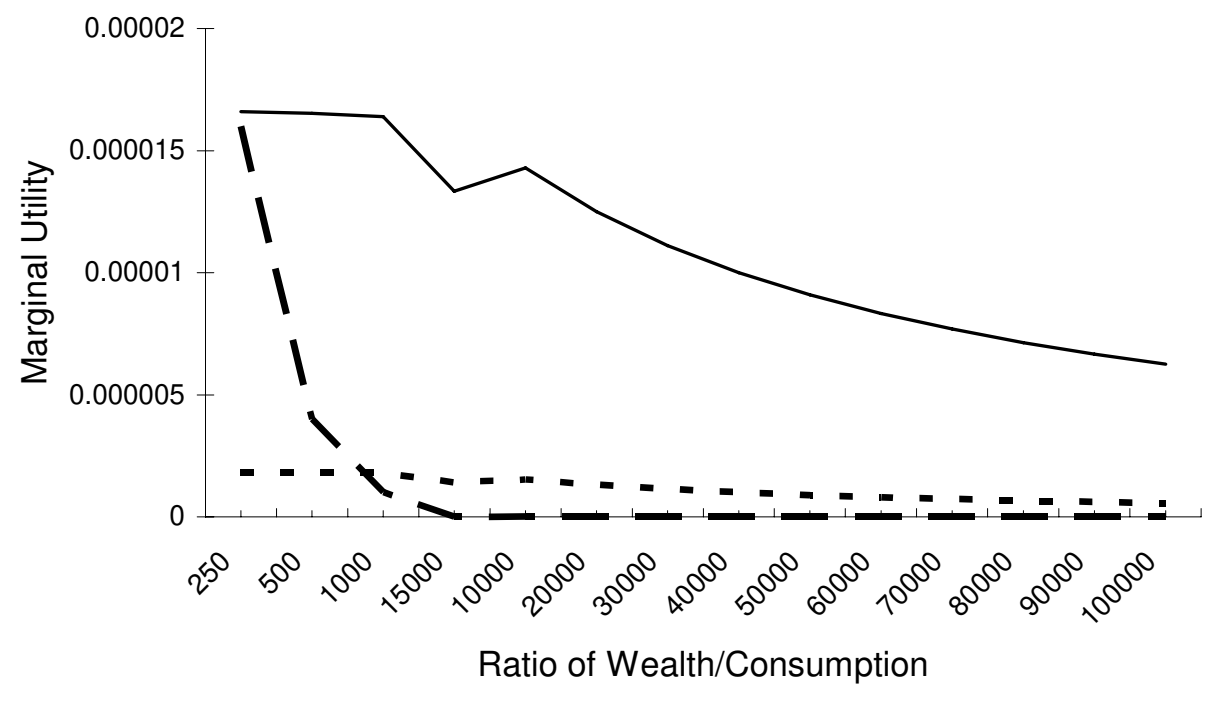

Note: The smooth line is the marginal utility of wealth when $\alpha=1$, the thickly dashed line is the marginal utility of consumption with $\rho=2$ and the small dotted line is the marginal utility of wealth when $\alpha=1.7$. 